\title{
Seasonal, Serological Markers and Platelet Count Association with Dengue Fever
}

\author{
Patta Apparao $^{1 *}$, D.K.V. Prasad ${ }^{2}$ and S.V. Lavanya ${ }^{1}$ \\ ${ }^{1}$ Department of Microbiology, ${ }^{2}$ Department of Biochemistry, NRI Medical College, \\ Visakhapatnam Andhra Pradesh, India \\ *Corresponding author
}

\section{A B S T R A C T}

Dengue fever is an emerging acute arbo-viral illness, affecting tropical and subtropical countries. Timely surveillance of dengue fever as well as vector control have utmost

\section{Keywords}

Dengue fever, NS1 antigen,

Thrombocytopenia

Article Info

Accepted:

18 September 2018

Available Online:

10 October 2018 importance. Our study has made an attempt to find out the association of dengue fever with seasonal variations and it's correlation with thrombocytopenia and haematocrit. This study was conducted in central laboratory section of NRI Medical College, Visakhapatnam, AP, from September 2017 to August 2018. Serum samples collected from suspected dengue fever cases were analysed for markers by using immunochromatographic card test. Selected Blood samples were also tested for platelet count and haematocrit by automation method. Of 2002 samples received, $1641(81.96 \%)$ sera were positive for one or more parameters of dengue. 1,032 were positive for NS1 only, 228 positive for IgM only and 381 positive for IgG only. Thrombocytopenia was present in $41.6 \%$ of selected cases and raised haematocrit in $48.14 \%$. There is a seasonal increase in the incidence of dengue cases during monsoon period. NS1 antigen detection helps in early diagnosis of dengue fever. Platelet count and haematocrit values are useful in the assessment of severity of dengue fever.

\section{Introduction}

Dengue is afebrile illness caused by a flavivirus transmitted by mosquitoes.

Approximately 50 million infections occur annually and dengue is the most rapidly spreading mosquito-borne viral illness (Davidson's Priniples). Dengue virus (DENV) is the most common arbovirus found in India. It is named after Swahili word "dinga" meaning fastidious or careful, which would describe the gait of a person suffering from the bone pain of dengue fever.it has four serotypes (DEN-1 to DEN-4). Recently, the fifth serotype (DEN-5) was discovered in 2013 from Bangkok (Aedes aegypti is the principal vector followed by Aedes albopictus (Rodenhuis-Zybert, et al., 2010; RodenhuisZybert, 2013).

Dengue virus can cause simple fever to life threatening complications. The complications such as dengue hemorrhagic fever (DHF) and dengue shock syndrome (DSS) are usually related to cross-reactivity between one 
serotype to other (Gubler, 1998). DHF is associated with 5\% mortality in most countries, mainly affecting young children and adults (World Health Organisation, 1995).

IgG/IgM detection are commonly used for diagnosis of dengue infection, but time required for appearance of $\operatorname{IgM}$ antibody is approximately 4-6 days. Dengue nonstructural 1 antigen (NS1) is highly conserved glycoprotein produced in both membrane associated and secretory forms is used as a new biomarker for early diagnosis of dengue infection (Subedi and Taylor-Robinson, 2014).

Immunochromatographic test is used for finding NS1 antigen in serum samples of patients as early as day one for presumptive diagnosis (Moorthy, et al., 2009).

Rainy season or post rainy season favours the collection of water in various sites like old tires, coolers, old earthenware pots, coconut shells etc. This acts as a good site for mosquito breeding. Hence, the vector thrives and disease incidence increases (Dash, 2005).

During the rainfall the mosquito population is high (3-4 female mosquitoes per house) as compared to the density during the dry season (1-2 female mosquitoes per house) (Huber, 2003).

\section{Materials and Methods}

This study was conducted in central laboratory, NRI Institute of Medical Sciences, Visakhapatnam, Andhra Pradesh from September 2017 to august 2018.

Blood samples from clinically suspected cases of dengue fever were collected. NS1 antigen detection, tests for $\operatorname{IgM}$ and $\operatorname{IgG}$ detection were done by using immunochromatographic card test.

\section{Platelet count}

EDTA blood samples were collected and the platelet count was done by automated analyser and cross checked by light microscopy in the pathology section of central laboratory, NRIIMS, Visakhapatnam and interpreted as normal, when the count was between 150000$450000 / \mathrm{cmm}$ and DHF, when the count was $1,00000 / \mathrm{cmm}$ (WHO cut off for platelet count for DHF). Haematocrit was also done.

\section{Results and Discussion}

A total number of 2002 blood samples collected during 12 months period were analysed for various parameters like NS1 antigen, $\operatorname{IgM}$ and $\operatorname{IgG}$ antibodies. Selected blood samples were also tested for platelet count and haematocrit.

Out of 2002 sera, 381 have shown positive for IgG (19.03\%). 228 were positive for $\operatorname{IgM}$ $(11.38 \%)$ and 1,032 positive for NS1 antigen $(51.54 \%)$ (Table 1$)$.

There is also a gradual increase in the number of NS1 positives, from the month of June indicating seasonal incidence of new cases occurring due to rainfall and associated change in ecosystem $(36.43 \%$ in June to $81.72 \%$ in the month of august).

It is also noticed an increase in the number of IgG positives in august (182 out of 580 i.e.31.37\%) suggesting secondary cases of dengue fever (Table 1). Repeated occurrence of dengue fever is more prone to lead to complications: dengue haemorrhagic fever and dengue shock syndrome.

Among 1641 seropositive cases, thrombocytopenia was found in 684 (41.6\%). From 1,032 NS1 positive samples, 700 were subjected to platelet count based on complications of dengue fever. 200 (28.5\%) 
out of 700 NS1positives have shown platelet count less than $1,00000 /$ cumm.51.4\% of NS1+IgM combination have shown thrombocytopenia. Maximum number of (97.5\%) thrombocytopenia cases were seen in
NS1+IgM+IgG combination (Table 2). Raised haematocrit values were observed in 790 $(48.14 \%)$ cases and normal range of haematocrit was seen in 851 cases $(51.86 \%)$ as shown in Table 3.

Table.1 Month wise distribution of dengue sero-positivity

\begin{tabular}{|l|l|l|l|l|}
\hline \multicolumn{1}{|c|}{ Month } & Total tested & IgG positive & IgM positive & NS1 positive \\
\hline September (2017) & 83 & & & \\
\hline October (2017) & 144 & 02 & 02 & 15 \\
\hline November (2017) & 98 & 04 & 11 & 24 \\
\hline December (2017) & 57 & 06 & 03 & 04 \\
\hline January (2018) & 18 & 01 & 03 & 04 \\
\hline February (2018) & 33 & 02 & nil & 01 \\
\hline March (2018) & 27 & 03 & nil & nil__ \\
\hline A pril (2018) & 33 & 02 & 01 & 01 \\
\hline May (2018) & 56 & 12 & nil & 06 \\
\hline June (2018) & 247 & 30 & 10 & 13 \\
\hline July (2018) & 626 & 126 & 30 & 90 \\
\hline August (2018) & 580 & 182 & 100 & 400 \\
\hline \multicolumn{1}{|c|}{ Total } & 2002 & $381(19.03 \%)$ & $228(11.38 \%)$ & $1,032(51.54 \%)$ \\
\hline
\end{tabular}

Table.2 Showing comparison of platelet count with various dengue parameters

\begin{tabular}{|l|c|c|c|}
\hline $\begin{array}{c}\text { Dengue serological } \\
\text { markers }\end{array}$ & $\begin{array}{c}\text { Total positive } \\
\text { serum samples }\end{array}$ & $\begin{array}{c}\text { Positives with platelet } \\
\text { count }<\mathbf{1 , 0 0 , 0 0 0 / m l}\end{array}$ & Percentage \\
\hline NS1 only & 700 & 200 & $28.5 \%$ \\
\hline NS1+IgM & 350 & 180 & $51.4 \%$ \\
\hline IgG only & 250 & 96 & $38.4 \%$ \\
\hline IgM only & 200 & 88 & $44 \%$ \\
\hline IgG+IgM & 98 & 80 & $81.6 \%$ \\
\hline NS1+IgM+IgG & 43 & 40 & $97.5 \%$ \\
\hline Total & 1641 & 684 & $41.6 \%$ \\
\hline
\end{tabular}


Table.3 Haematocrit levels

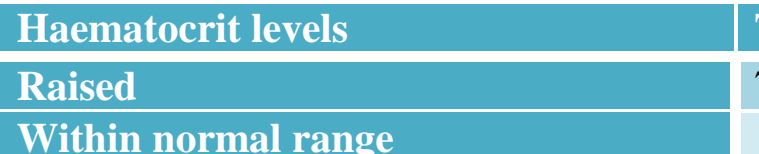

Dengue fever and it's complications like dengue hemorrhagic fever, dengue shock syndrome, disseminated intravascular clotting are recognised as important emerging public health problems in tropics and subtropics. This is the reason for making early diagnosis of dengue, with the help of clinical parameters like platelet count, haematocrit and serological markers to reduce morbidity and mortality in dengue.

Climatic factors responsible for epidemics either alone or in combination are rainfall, variation in temperature and sometimes humidity (Kahn, 2014; Soumya and Jayasankarankutty. 2014).

Our study identified an increase in dengue cases during July and august months. This finding is in accordance with that of Khan DM et al., The antibodies begin to appear on fifth day of fever in primary infection (Kulkarni, et al., 2011; Peeling, et al., 2010).

The present study was observed a platelet count below $100000 / \mathrm{cmm}$ only in 200 samples out of 700 NS1 positives $(28.5 \%)$. This finding is in contrast to that of Santosh Shivajirao, et al., 2013. However, we found 97.5\% fall in platelet count of below $1 \mathrm{lakh} / \mathrm{cmm}$ in $\mathrm{NS} 1+\operatorname{IgM}+\operatorname{IgG}$ combination. Dengue fever is more common during rainy season. Thrombocytopenia is associated with certain combination of antigen antibody markers. Haematocrit values also increase in dengue fever.

\section{References}

Dash PK, Saxena P, Abhavankar A, Bhargava
Total number of cases

851

51.86 percentage

48.14

$\mathrm{R}$ and Jana AM. Emergence of dengue virus type 3 in Northern India. Southeast Asian J Trop Med Public Health 2005; 36:370-77

Davidson's principles and practice of medicine $22^{\text {nd }}$ edition. page 322 .

Gubler DJ. Arboviruses (Togaviridae and Flaviviridae) In: Mahy BWJ, Collier L, Topley and Wilson's microbiology and microbial infections, 9th edition, London: Arnold; 1998:579-600

Huber K, Loan LL, Hoang TH, Teen TK, Roahain F, and Failloux AB. Aedesaegypti in South Vietnam Ecology, genetic structure, vectorial competence and resistance to insecticides. Southeast Asian J Trop Med Public Health 2003; 34(1): 81-86.

Kahn DM, Kuppuswamy K, Sumathi S, Mrinalini VR; Evaluation of thrombocytopenia in dengue infection along with seasonal variation in rural Melmaruvathur. $J$ of Clin.Diagn.Research; 2014; 8(1): 39-42.

Kulkarni RD, Patil SS, Ajantha GS, Upadhyaya AK, Kalabhavi AS, Subhadra RM et al., Association of platelet count and serological markers of dengue infection- importance of NS1 antigen. Indian Journal of medical microbiology. 2011; 29(4):359-62.

Moorthy M, Chandy S, Selvaraj K, Abraham AM; Evaluation of a rapid immunochromatographic device for the detection of $\operatorname{IgM}$ and $\operatorname{IgG}$ antibodies to dengue viruses (DENV) in a tertiary care hospital in south India. Indian J Medical microbiology; 2009; 27(3):254-256.

Normile D. "Surprising new dengue virus throws a spanner in disease control 
efforts". Science 2013; 342 (6157): 415).

Peeling RW, Artsob H, Pelegrino JL, Buchy P, Cardosa MJ, Devi S et al., Evaluation of diagnostic tests: Dengue.Nat.Rev Microbiol.2010;8:S30-37.

Rodenhuis-Zybert IA, Wilschut J, Smit JM.” Dengue virus life cycle: viral and host factors modulating infectivity". Cell. Mol. Life science. August 2010; 67(16): 2773-86.

Santosh Shivajirao T, Chincholkar VV, Kulkarni DM, Nilekar SL, Ovhal RS and Halgarkar CS. A study of NS1 antigen and platelet count for early diagnosis of dengue infection. Int.J. Curr. Microbiol. App. Sci 2013; 2(12): 40-44.
Soumya K; Jayasankarankutty. Seroprevalence and seasonal trend of Dengue virus infection at a teaching hospital in Tumkur, India. Sch. J. App. Med. Sci; 2014; 2(3A):922-926.

Subedi D and Taylor-Robinson AW. Laboratory diagnosis of dengue infection: current techniques and future strategies. Open journal of Clinical Diagnostics.2014; 4:63-70

World Health Organisation. Key issues in dengue vector control towards the operationalisation of a global strategy: report of consultation. Geneva: WHO; 1995. (CTD/FIL(DEN)/IC.96.1

\section{How to cite this article:}

Patta Apparao, D.K.V. Prasad and Lavanya, S.V. 2018. Seasonal, Serological Markers and Platelet Count Association with Dengue Fever. Int.J.Curr.Microbiol.App.Sci. 7(10): 25132517. doi: https://doi.org/10.20546/ijcmas.2018.710.291 